\title{
SUSTAINABILITY OF FISHERY POND POLYCULTURE WITH AND WITHOUT MANGROVE INTEGRATION
}

\author{
Eva Dolorosa ${ }^{*}$, Masyhuri ${ }^{2}$, Lestari ${ }^{2}$, and Jamhari ${ }^{2}$ \\ ${ }^{1}$ Faculty of Agriculture, Tanjungpura University, Pontianak \\ *E-mail: edolorosa@gmail.com \\ ${ }^{2}$ Faculty of Agriculture, Gadjah Mada University, Yogyakarta
}

\begin{abstract}
This research aims to analyze the sustainability of two types of fishery pond polyculture of milkfishtiger shrimp with and without mangrove integration on small-scale farms. Sustainability dimensions considered in this research included are the ecology, economy, social-culture, technology-infrastructure, and laws-institutions as the dimensions analyzed. The performance of each aspect was analyzed by using Multi-dimensional scaling (Rapfish) and leverage analysis. The result shows that the current multidimensional sustainability status of the fishery pond polyculture both with and without mangrove integration was less sustainable (sustainability index of 44.98 and 36.18 respectively). The result of leverage analysis indicates that out of 73 attributes, there were 16 and 23 sensitive attributes respectively that affect the sustainability of polyculture fishpond with and without mangrove integration. These attributes should be managed immediately in order to improve the sustainability index of fishery pond polyculture, this includes organic pesticides application, source of capital, the availability of seeds of milkfish and tiger shrimp, market location, selling price, waste treatment technology, availability of agribusiness facilities and infrastructure, aquaculture technology, information technology, standardizing the quality of fishery products, availability of micro finance institution and others.
\end{abstract}

Keywords: milkfish-tiger shrimp, sustainability, mangrove, fishery pond, polyculture, Rapfish

\section{ABSTRAK}

Penelitian ini bertujuan untuk menganalisis keberlanjutan dua tipe tambak perikanan skala kecil, yaitu tambak polikultur bandeng-udang windu yang berintegrasi dan tanpa integrasi mangrove. Dimensi keberlanjutan dalam penelitian ini meliputi dimensi ekologi, ekonomi, sosial-budaya, teknologiinfrastruktur, dan hukum-lembaga. Kinerja setiap aspek dianalisis dengan menggunakan skala multidimensi (Rapfish) dan analisis leverage. Hasil penelitian menunjukkan bahwa kedua tambak perikanan polikultur dengan dan tanpa integrasi mangrove, status keberlanjutan multidimensinya adalah kurang berkelanjutan (indeks keberlanjutan masing-masing adalah 44,98 dan 36,18). Hasil analisis leverage menunjukkan bahwa dari 73 atribut, terdapat 16 dan 23 atribut-atribut yang mempengaruhi keberlanjutan masing-masing perikanan tambak yang terintegrasi dan tanpa terintegrasi dengan mangrove. Atribut-atribut ini perlu dikelola segera untuk memperbaiki indeks keberlanjutan perikanan tambak ini, antara lain adalah penggunaan pestisida organik, permodalan, tersedianya bibit bandeng dan udang windu, lokasi pasar, harga jual, pengolahan limbah perikanan, tersedianya fasilitas dan infrastrukstur perikanan, teknologi budidaya perikanan, teknologi informasi, standarisasi kualitas produk perikanan, ketersediaan lembaga keuangan mikro, dan lainnya.

Kata kunci: bandeng-udang windu, keberlanjutan, mangrove, tambak perikanan, polikultur, Rapfish

\section{INTRODUCTION}

Fishery contributes to human welfare by providing a livelihood and protein supply for millions of people. Many studies indicate that fishery sector around the world is curently facing problems. These problems will not only affect the ecology condition, but also the economic and social conditions of people engaged in fishery activities (Thomson, 2008). So, sustainable development in the fishery sector is very important. Sustainable development refers to the management and conservation of natural resources based on the 
orientation of technological and institutional changes in such a way to ensure the attainment and continued satisfaction of human needs for present and future generations. Such sustainable development (in the agriculture, forestry and fishery sectors) which conserves land, water, plant and animal genetic resources, is environmentally non-degrading, technically appropriate, economically viable and socially acceptable (FAO, 1997).

There has been a decrease in the total catch of fishery, from the sea, rivers and lakes. Production from fishery capture in the AsiaPacific region is estimated to decline over the next 10 - 20 years, unless the excess capacity is greatly reduced (Sugiyama et al., 2004), so that aquaculture be an option to meet consumer demands of fishery products.

Furthermore, aquaculture in fishery is one of economic activities of people who need the sustainability of economic (efficiency and growth), social (ownership, employment), and ecology (protection of natural resources and the environment) sustainability. Increased aquaculture production without awareness to the environment will not be able to maintain the sustainability of fishery business in the future. Some researchers argue that aquaculture can create environmental damage or social unrest. However, aquaculture is also a source of protein, employment, income and foreign exchange. Therefore, aquaculture should not only be profitable, but also socially acceptable and protecting the environment (Nathanael et al., 2002).

Another form of aquaculture is polyculture, which is known as multi-trophic aquaculture, co-culture or integrated aquaculture (Bunting, 2008). In shrimp farming, this approach has several benefits, such as lessening the risk of ecology impacts, improving the yield of both the primary and secondary stocks and maintaining optimum water quality in a particular aquaculture system (Muangkeow et al., 2007; Troell et al., 2009). It also effectively utilizes different natural food present in the production area, thus improving efficiency of converting avai- lable resources to end products. There have been several studies that demonstrate the beneficial effects of culturing shrimps with other aquatic species, for example shrimps that are polycultured with other fish such as tilapia, several species of macroalgae and shellfish (Akiyama et al., 1999; Bunting, 2006; Da-Silva-Copertino et al., 2009). The use of these secondary species in shrimpfishponds provides such benefits as reducing the amounts of dissolved nutrients, filtering suspended solids, feeding on excess organic matter, improving water quality and enhancing disease resistance against pathogens (Martinez et al., 2010). Markus and Burhanuddin (2014) stated that, polyculture of tiger shrimp, milkfish and seaweed is a commodity polyculture mutually synergistic compared to polyculture of two commodities on traditional fishponds, because it is more profitable, and provides added values On the other hand, pond management in polyculture system becomes more difficult when stocking fish species in the same pond has specialized feeding habits because good fertilization and feeding practices must be followed (Bocek, 2015).

Sustainable polyculture that integrates fishery products with forest plants is called silvofisheries. It is a form of low input aquaculture integrating mangrove tree culture. The objective of silvofisheries is maintaining the existence of mangrove through mangrove planting in and around fishponds. This approach at the same time conserves mangroves and maintains the sustainability of fisheries products (Surtida, 2000)

Sambas Regency is located in the northern part of West Kalimantan Province, facing the Natuna Sea. It is, on the border of Sarawak (Malaysia). In Sambas Regency, aquaculture production increased from 55.53 tons in 1993 and 880.20 tons in 2003 to almost 5 thousand tons in 2012, valued at over Rp. 148 billion or equal to US $\$ 11.4$ million. The sector' production is growing at an average rate of more than 5\% per year (BPS Sambas, 2013). Most of aquaculture in this region is 
polyculture of milkfish (Chanos chanos) and tiger shrimp (Penaeus monodon) in smallscale farms that belong to local communities. Polyculture of milkfish and tiger shrimp is introduced as a strategy to efficiently utilize natural food production in fishponds and to maximize revenue to fish-farmers. The polyculture area is located on the coastal area, which was originally mangrove inhabited area and converted into aquaculture fishponds. So, the existence of the mangrove inhabited area is now greatly reduced because of the expansion of aquaculture farms in the coastal area. This aligns with other research which stated that mangroves are widely recognized as one of the most highly threatened global ecosystems, with the principal cause of rapid conversion to aquaculture farms (Spalding et al., 1997).

Traditional pond management has been done by some of the local communities as they keep cultivating mangrove plant and integrating it to polyculture of milkfish tiger shrimp. On the other hand, the other fishfarmers are just utilizing milkfish tiger shrimp polyculture without mangrove integration. The importance of this research is that this research type has not been done extensively yet and the result of this study may help us understand the sustainability status and the sensitive attributes that affect the sustainability factors of fish ponds polyculture nowadays, so fish farmers and stakeholders may create a prospective strategy in maintaining and improving the sustainability of polyculture ponds and mangroves. The objectives of this research are (a) to determine the index and sustainability status of two types of fishery pond polyculture on small-scale fish-farms based on the dimensions of ecology, economy, social-culture, technology-infrastructure, and laws-institutions, (b) to identify sensitive attributes that affect the sustainability of fishery pond polyculture.

\section{MATERIAL AND METHODS}

This research was conducted in five villages of Sambas Regency, West Kaliman- tan, namely: Pemangkat Kota, Jelu Air, Jawai Laut, Sarang Burung Usrat and Sarang Burung Danau. The research sites were purposively determined based on several considerations. One of which is, that this location has many milkfish-tiger shrimp polyculture fishponds around the coastal area with mangroves integration and fishponds without mangrove integration. In addition, most of the people who live in this regions are relying their living on aquaculture. The total number of respondents are rounded to 150 fish-farmers who cultivate polyculture of milkfish (Chanos chanos) and tiger shrimp (Penaeus monodon). Multidisciplinary approach to sustainability was using Rapfish, a rapid appraisal technique that evaluates the sustainability status of fishery based on the transparent and semi-quantitative scoring of sets of ecology, economy, social, technological and ethical attributes (Spalding et al., 1997; Pitcher and Preikshot, 2001; Garcia et al., 2000). Rapfish uses simple and easily scored attributes to provide a rapid, costeffective, and multidisciplinary appraisal of the status of a fishery, in terms of comparative levels of sustainability (Spalding et al., 1997; Tesfamichael and Pitcher, 2006). It has been used to compare the sustainability status of many fisheries (Garcia et al., 2000; Tesfamichael and Pitcher, 2006; Preikshot et al., 1998; Alder et al., 2000; Baeta et al., 2005). The Rapfish method combines expert-driven fishery sustainability indicators (Allahyari, 2010).

Some criteria can be used as references for sustainable development, which include ecology, economy, social culture, technological and law-institutional criteria (Pitcher, 1999; OECD, 1993). This research used five dimensions, namely ecology, economy, social culture, technology infrastructure, and law institutional dimensions, comprising a total of 73 attributes to evaluate the sustainability. These attributes were confirmed to the local stakeholders in order to generate a "locally accepted" fishery sustainability attributes. Each attribute was 
scored according to the information collected in field samplings, which include direct observations, interviews of fish-farmers and stakeholders, and official information from some institutions. Attribute scores were normalized so that they all have equal weight in the analysis. The scoring results were then analyzed to determine multidimensional one or several points reflecting pond fishery sustainability positions, which were examined relative to two reference points: good points (good) and bad points (bad). The index scale and sustainability status of polyculture fishponds have studied interval of $0-100$. In this study, there are four categories of sustainability status as shown in the following Table 1.

Table 1. Category index and sustainability status.

\begin{tabular}{ll}
\hline Index Value & Category \\
\hline $0,00-25,00$ & Bad (not sustainable) \\
$25,01-50,00$ & Less (less sustainable ) \\
$50,01-75,00$ & Enough (fairly sustainable) \\
$75,01-100.00$ & Good (sustainable) \\
\hline
\end{tabular}

Source: Bourgeois and Jesus, 2004.

Uncertainty was expressed for each evaluation field using Monte Carlo sampling from normal distribution with $95 \%$ confidence interval (Kavanagh and Pitcher, 2004).
A leverage analysis was performed to identify the different attributes that have the largest proportional influence on the results. Rapfish provides a rapid assessment as to the "health" or sustainability status of fishery separately for each of the five evaluation fields. The results can also suggest where to emphasize future research and the wise use of limited resources (Pitcher, 1999).

\section{RESULTS AND DISCUSSIONS}

\subsection{Sustainability Status}

Multidimensional sustainability status for polyculture ponds both with and without mangrove integration was less sustainable (sustainability index of 44.33 and 36.18 respectively). Even though all the two type of polyculture fishponds showed less sustainability, the sustainability index of polyculture fishponds without mangrove integration showed a lower sustainability index (Figure 1b) than polyculture fishpond with mangrove integration (Figure 1a).

Mangrove ecosystem plays an important role in supporting the efforts of aquaculture fishery fishponds. Thus, it showed that the fishpond polyculture with mangrove integration is more sustainable. It is seen from its higher sustainability index on the dimension of ecology, economy, technology-infrastructure, and law-institutional (Figure 2a).

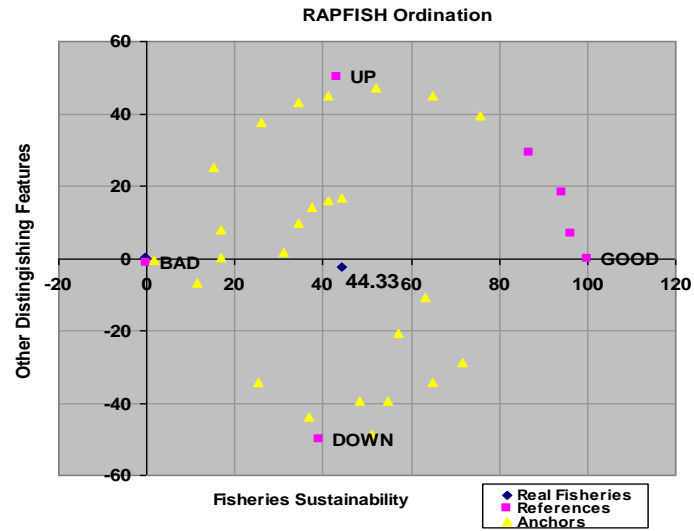

(a)

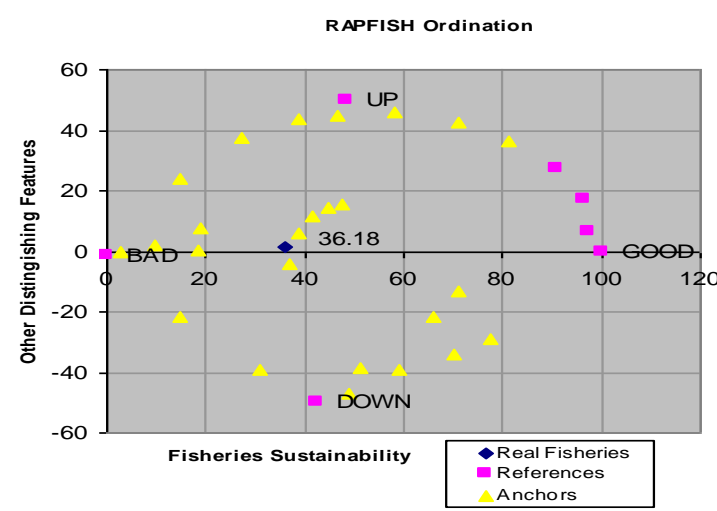

(b)

Figure 1. Multidimensional sustainability index of (a) polyculture fishponds-integrated mangroves; (b) polyculture fishponds-without integrated mangroves. 


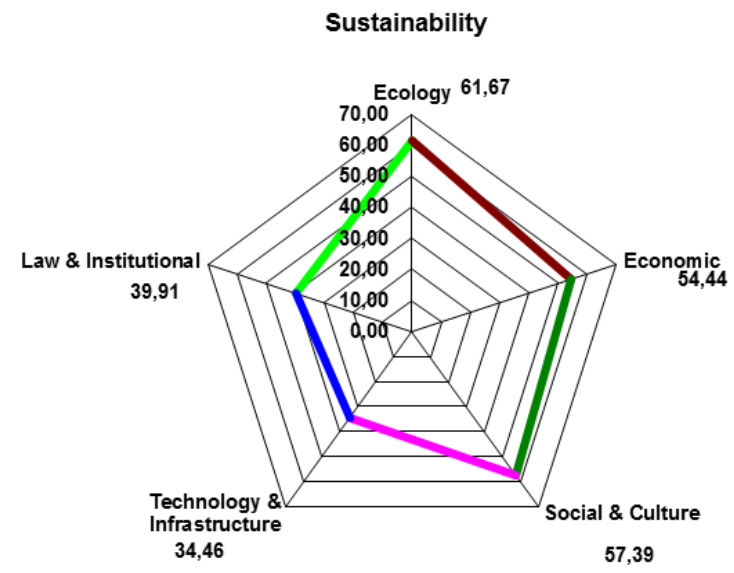

(a)

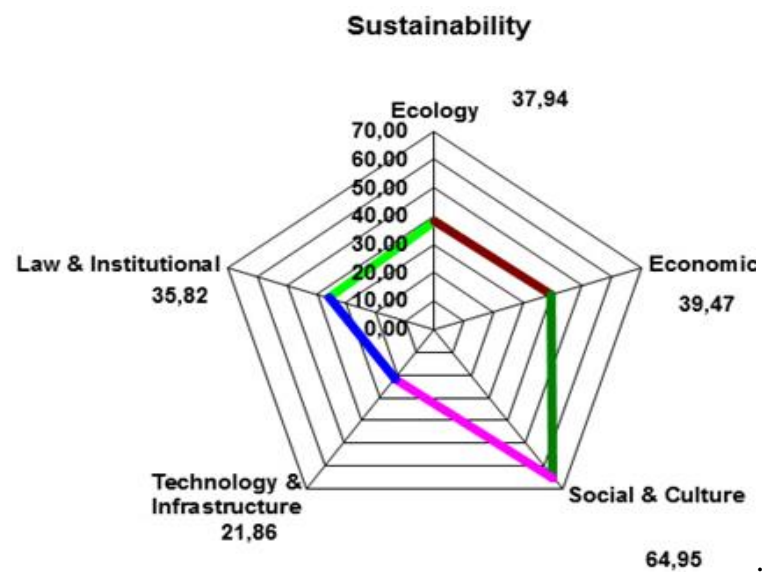

(b)

Figure 2. Kite diagrams of sustainability index of (a) polyculture fishponds-integrated mangroves (b) polyculture fishponds-without integrated mangroves.

The analysis of the Monte Carlo, showed that the error in the MDS analysis can be minimized. The analysis results were considered accurate and reliable when the stress value was smaller than 0.25 and the coefficient of determination (RSQ) value is close to 1.0 (Bourgeois and Jesus, 2004). MDS analysis indicated that all attributes that were examined and assessed were accurate and accountable.

Rapfish MDS analysis showed that the sustainability index of technology-infrastructure and law-institutional dimension was less sustainable, while ecology, economy and social-culture dimensions showed fairly sustainable in polyculture fishponds with mangrove integration (Figure 2a). On the other hand, the polyculture fishponds without mangrove integration showed that the sustainability index of technology-infrastructure was not sustainable, while ecology, economy and law-institutional dimensions were less sustainable, and social-culture dimension showed fairly sustainable (Figure $2 b$ ).

\subsection{Ecology Dimension}

In order to assess ecology sustainability, twenty attributes was measured in the analysis. It is very prominent that the sustainability status of ecology dimension of polyculture fishponds with mangrove integra- tion was fairly sustainable (index 61,67), otherwise polyculture fishponds without mangrove integration is less sustainable (index 37,94). This is because mangroves play an important role in the absorption of contaminants (pollutants) in ponds by reducing the level of pollution in nature, thus preventing the collapse of aquaculture fishery due to liquid waste that it generates, such as high levels of nitrogen and phosphorus (Pramudji, 2000; Ronnback et al., 1999). Also, mangroves have an important function to support environments, namely the high productivity of the production of leaf litter decomposed by the detritus which becomes particles of organic materials that can be utilized by biota farming as a source of natural food (Hogarth, 1999). Furthermore, mangroves physically act as a buffer abrasion where the root system is able to withstand and precipitate sludge and can be a buffer zone to reduce the damage caused by storms and ocean waves (Kathiresan and Bingham, 2001).

Based on the leverage analysis there was one sensitive attribute (organic pesticide application on polyculture fishponds with integrated mangroves (Figure 3a) and three sensitive attributes (temperature, vitamin and organic pesticide application) on polyculture fishponds without integrated mangroves 
(Figure 3b). These sensitive attributes should intervene to improve the sustainability status of these small-scale farms. Intervention to sensitive attributes is a shared responsibility of all stakeholders.

Some of fish-farmers applied inorganic pesticides to eradicate unwanted species and predators, which will disrupt the lives of milkfish and shrimp in ponds. The use of inorganic pesticides will accumulate and can harm aquatic environments and mangrove areas around the ponds. Inorganic pesticide residue will damage the structure of land, when accumulated due to continuous usage (Soeseno, 1998), and would degrade water quality and pond bottom soil, so that the ponds will become unproductive.

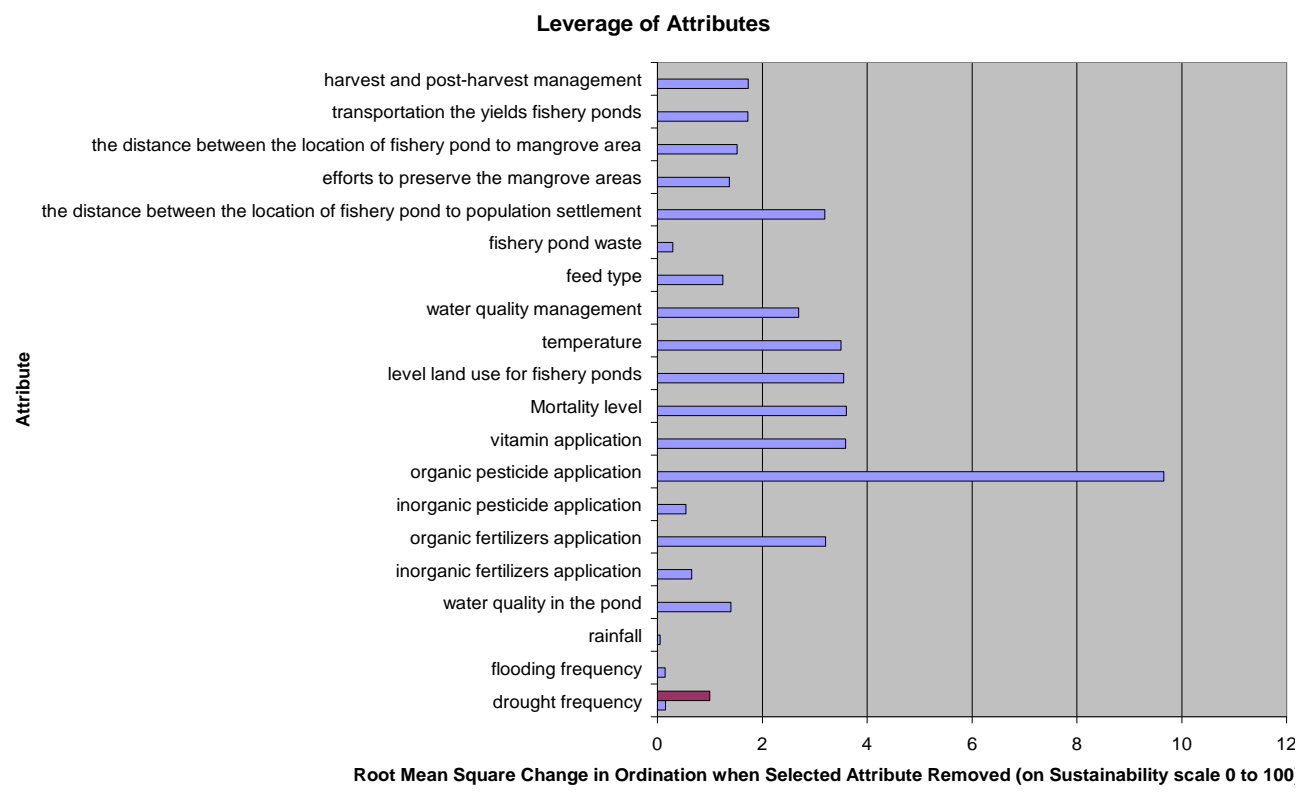

Figure 3a. Sensitive attributes affecting sustainability of ecology in fishery pond polyculture with mangrove integration.

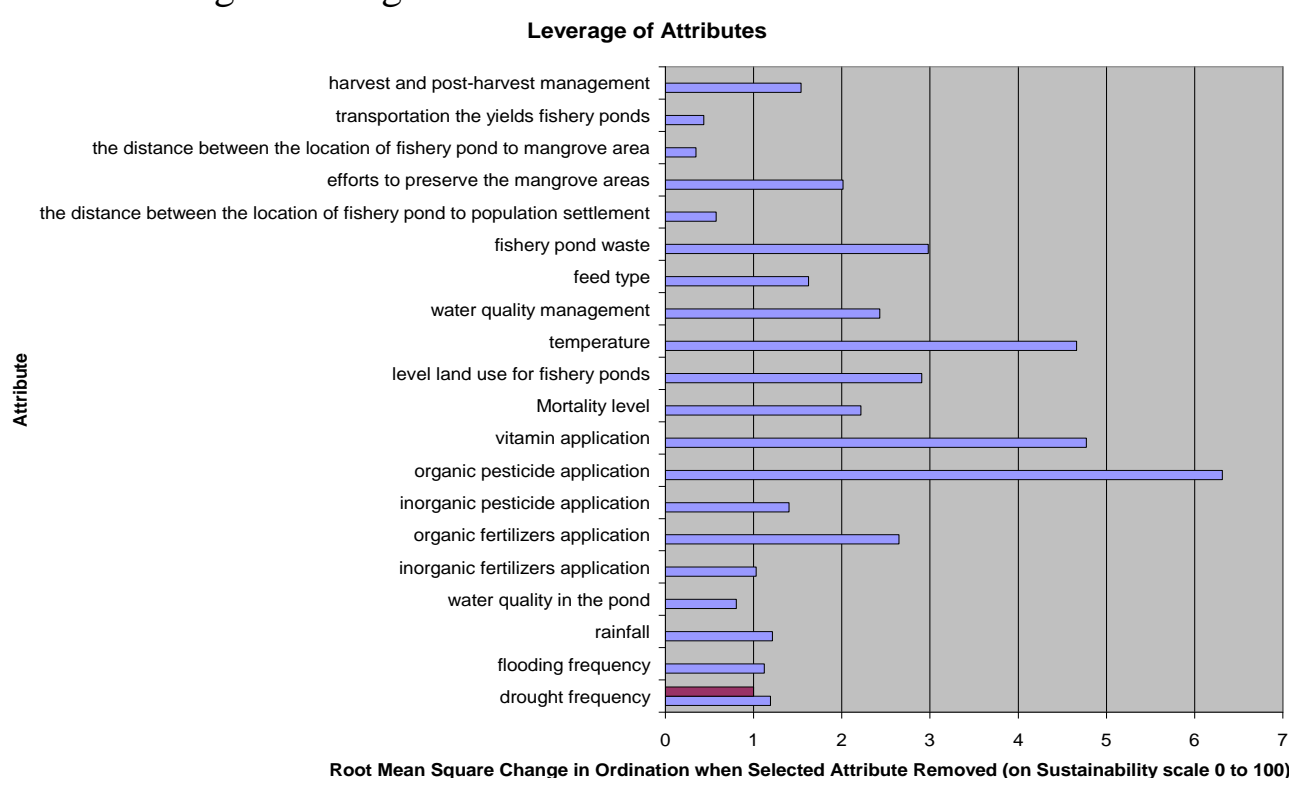

Figure $3 \mathrm{~b}$. Sensitive attributes affecting sustainability of ecology in fishery pond polyculture without mangrove integration. 
In the long term, the ponds cannot be used (Sudradjat, 2011). Eradication of pests can be done mechanically by capturing wild fish using a variety of fishing gear, or chemically by applying organic pesticides such as tobacco, tea seeds and tuba roots (Fahmi, 2000; Darmono, 1991). The fish farmers should always monitor the temperature of the pool and the provision of vitamins as needed to maintain and increase production of milkfish and tiger shrimp.

\subsection{Economy Dimension}

Based on analysis of 19 economy attributes, the sustainability status of economy dimension of fishery pond polyculture with mangrove integration was fairly sustainable (index 54,44), on the other hand, fishery pond polyculture without mangrove integration is less sustainable (index 39,47).

There were 5 sensitive attributes (source of capital, milkfish and tiger shrimp seeds availability, market location, selling price of milkfish and tiger shrimp, and the ability of the market to buy fish products) on polyculture fishponds with integrated mangroves (Figure 4a), and there were 8 sensitive attributes (source of capital, percentage of poor population, financial feasibility of pond fisheries, fluctuation in production, the ability of the market to buy fish products, market location, milkfish and tiger shrimp seeds availability, and profit transfer) on polyculture fishponds without integrated mangroves (Figure 4b). The need for intervention to these attributes were expected to improve economy sustainability.

Usually, fish farmers obtain loans from various non formal financial institutions that exist in the villages, and repaid back loans after the harvest. This finance system is prone to risks and uncertainties of fisheries production, and it will also be a psychological burden for the farmers. In the future, authorized financial institutions to support fundings should exist in this area. Other sensitive attribute is there is no seeds supply from local suppliers, farmers buy milkfish and shrimp seeds from Bali and Makassar in a relatively expensive price.

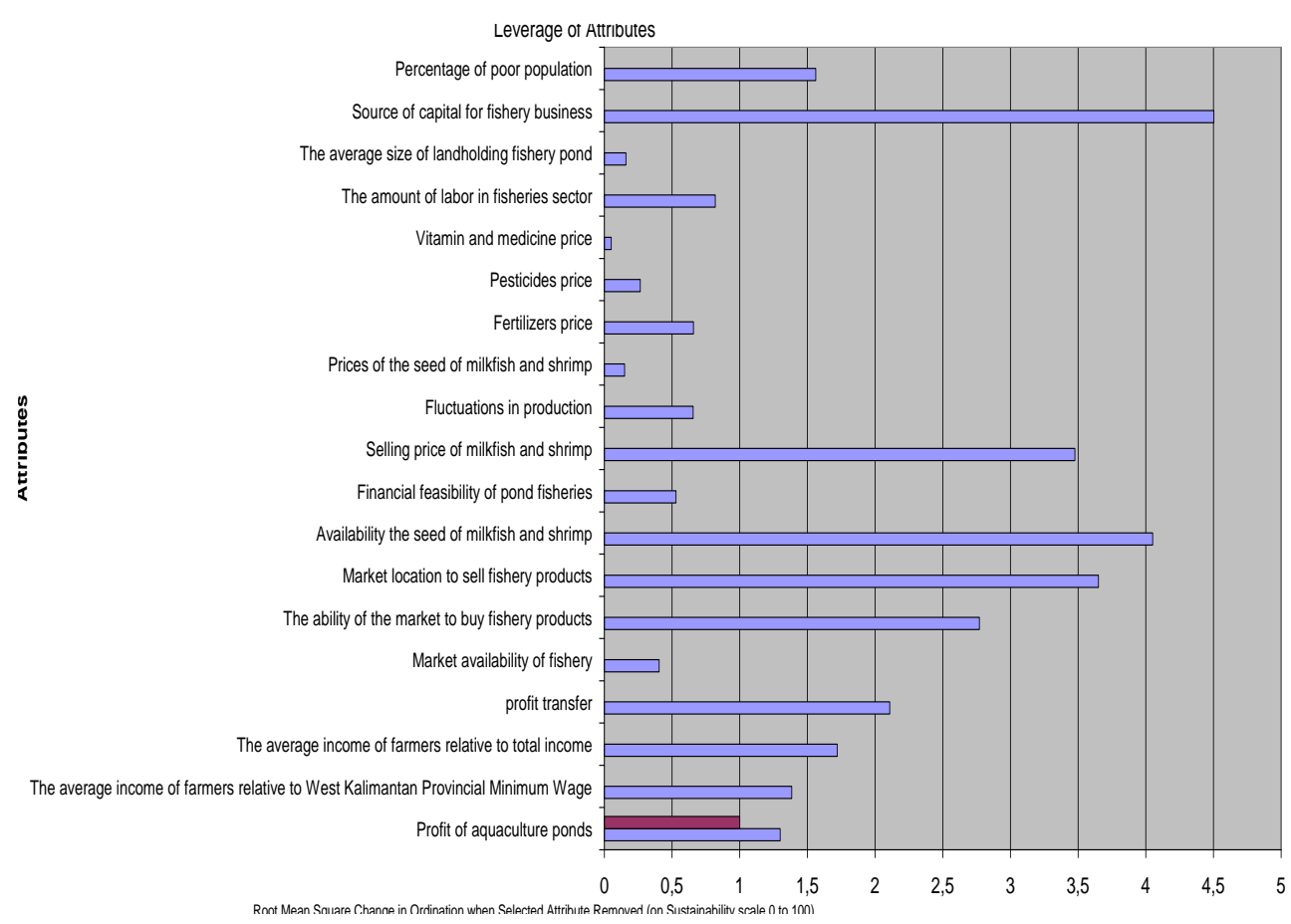

Figure 4a. Sensitive attributes affecting sustainability of economy in fishery pond polyculture with mangrove integration. 
Sustainability of Fishery Pond Polyculture ...

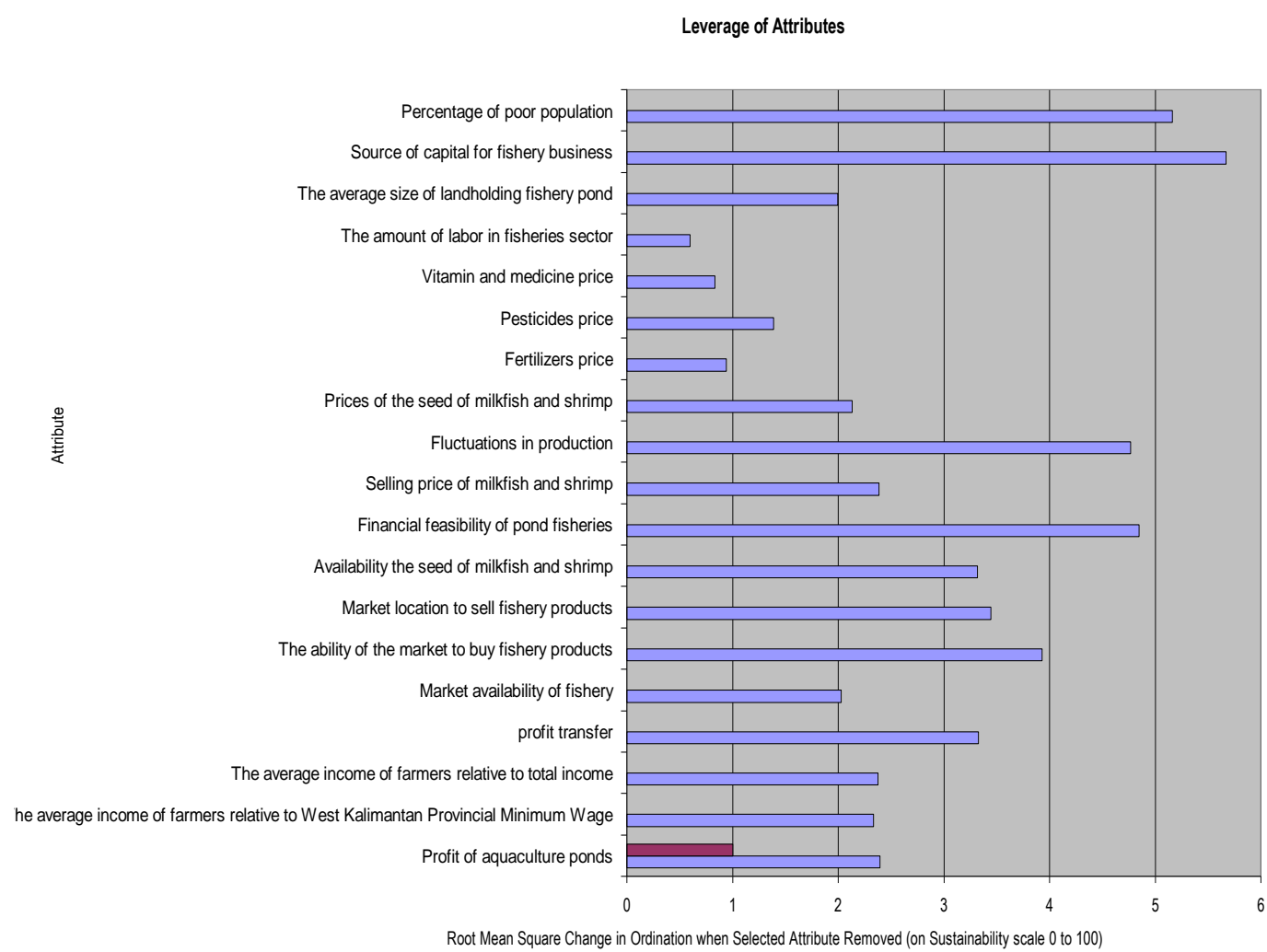

Figure 4b. Sensitive attributes affecting sustainability of economy in fishery pond polyculture without mangrove integration.

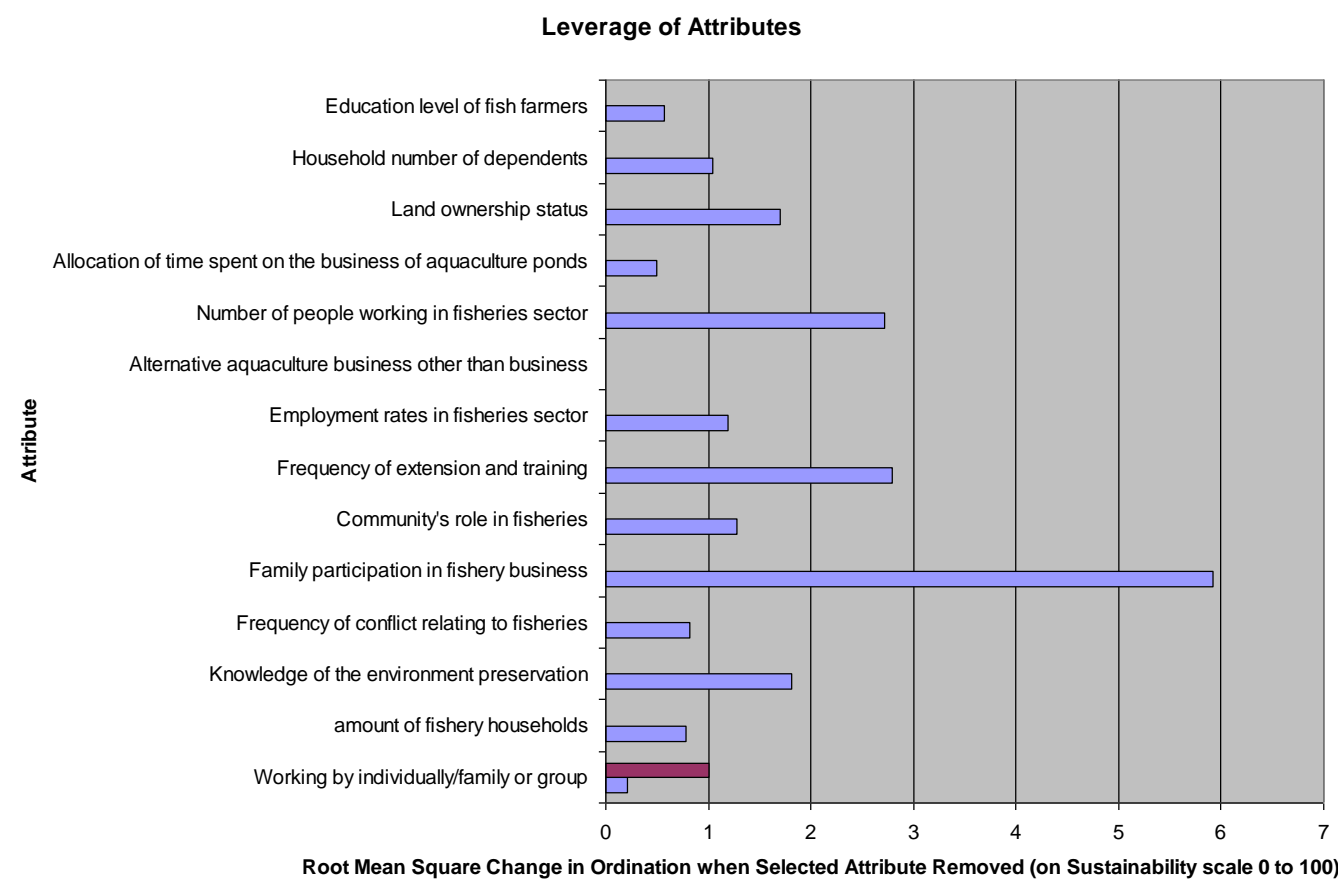

Figure 5a. Sensitive attributes affecting sustainability of social-culture dimensions in fishery pond polyculture with mangrove integration. 


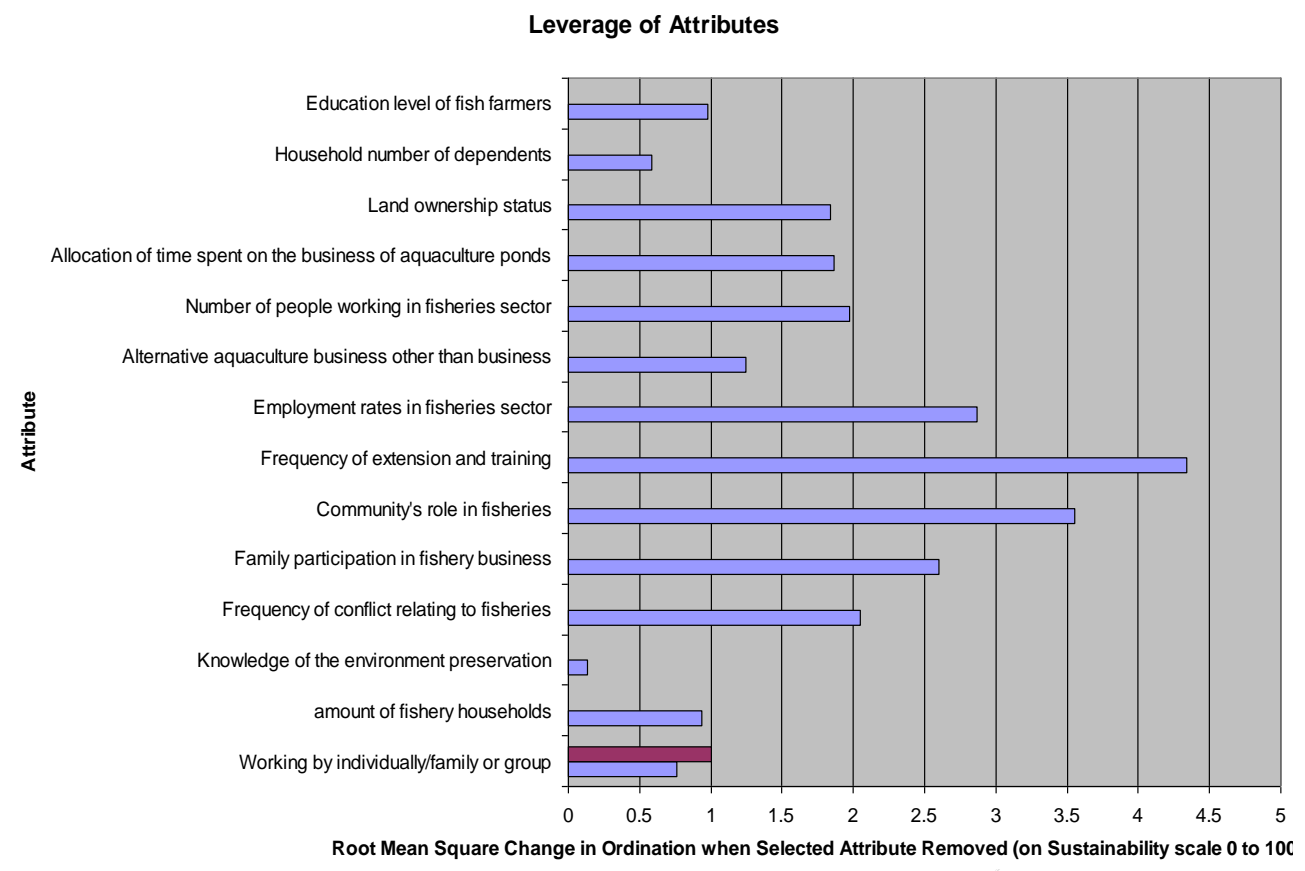

Figure 5b. Sensitive attributes affecting sustainability of social-culture dimensions in fishery pond polyculture without mangrove integration.

The absence of hatchery in Sambas district is the main problem. Farmers found it difficult to obtain milkfish and shrimp seeds at the right time. Thus, it was necessary to develop milkfish and shrimp hatchery in Sambas district, so that farmers can easily buy seed of milkfish and tiger shrimp at an affordable price.

\subsection{Social Culture Dimension}

Sustainability status in social culture dimension of both ponds was fairly sustainable (sustainability index of 57,39 and 64,95 respectively). Based on 19 attributes were expected affect the sustainability of the social-culture dimensions, there was one sensitive attribute (family participation) on polyculture fishponds with integrated mangroves (Figure 5a) and four sensitive attributes (frequency of extension and training, community role in fisheries, employment rates in fishery, and family participation) on polyculture fishponds without integrated mangroves (Figure $5 b$ ).

There has been a decline in the participation of family members in aquaculture activities. It is also associated with a decrease in the level of employment in the fisheries sector. Some of the causes are because of the fact that farmers' children attend schools outside their hometown, and after graduation they do not want to go back to the area to continue aquaculture business. The lack of interest in doing aquaculture business and the lack of most farmers' awareness to the existence and importance of mangrove functions for support and maintain the sustainability of aquaculture fishery, also become the causes of the low role of the community in fisheries. This situation needs to be improved in the future by inviting members of the family and the community to participate in continuing the effort and protecting the environment so that the mangrove area of aquaculture fisheries can produce fish products in a sustainable manner. Also, the government (Marine and fisheries office) should increase extension and training activities on aquaculture and harvesting techniques, also recognizing the function of mangroves in protecting the ponds' 
environment that will improve the quality of fishery products.

\subsection{Infrastructure Technology Dimen- sion}

According to the result from MDS, sustainability index of technology-infrastructure dimension of polyculture fishponds with mangrove was less sustainable (index 34,46), whereas, polyculture fishpond swithout mangrove had the sustainability index 21,86 , which is indicated as not sustainable. There were eight sensitive attributes of technologyinfrastructure dimension (technology of fishery products processing, waste treatment technology, feeding technology, availability of public facilities and infrastructure, availability of agribusiness facilities and infrastructure, aquaculture technology, availability of information technology, and standardize the quality of fishery products) on polyculture fishponds with mangrove (figure 6a), and two sensitive attributes (availability of public facilities and infrastructure, availability of information technology, he use of water pumps) on polyculture fishponds without inte grated mangroves (Figure 6b).

Waste treatment technology is still not developed yet. Types of waste from the pond in the form of organic waste from sludge consists of a mixture of soil, faeces, aquaculture effluents, sediment runoff from fertilizers and pesticides. Remains of organic waste in the form of fish, tiger shrimp, other wild fish with poor quality is disposed around the ponds area, when farmers drying their ponds, water from the pond immediately flowing in to the nearby waters (small rivers/sea). Kioussis et al. (2000) mentions that from aquaculture wastewater effluents, natural waters may be contaminated, and the quality is declining, by the discharge of pollutants such as nitrate, nitrite and phosphate. The high NO3, NO2, and PO4 concentration is usually found in waste water discharge from the circulation system of aquaculture production. This is in accordance with the opinion of $\mathrm{Ng}$ et al. (1993); Stickney
(1994); Sauthier et al. (1998) in Islam (2005), which states that at a high enough level of anion concentration of nutrients can be toxic to fish or may cause blooming of phytoplankton and the rapid growth of filamentous algae or macrophytes undesirable. Stickney (1994) in Islam (2005) stated that blooming algae leading to lower concentration of dissolved oxygen (DO depletion) in water and can lead to fish mortality. The pesticide give effect to all taxonomic groups of organisms and not only the target creature, but almost all living beings are exposed (Connell and Gregory, 2006). It all will lead to environmental degradation and declining fishery production, therefore, the government is expected to train farmers on waste water treatment technology.

There is no fishery product processing facility in this research location, because fish farmers do not understand the technology of fishery product processing such as the manufacture of milkfish Presto (boiling with pressurized boiler), processed meat fish into fish balls or other foods. Some improvement needed is processing training, provision of processing technology equipment, and market information for processed products.

Infrastructure such as road access to the fish-pond was not adequate. Almost all roads around the area of ponds in the form of a small road land, if the rain conditions are often not able to pass by vehicle so that farmers use a small boat to get to the ponds. This greatly affects the activity of aquaculture activities, like controlling the water, and selling products. Others are the unavailability of excavator to rehabilitate farmer's ponds. Generally, farmers dig and remove sludge from the pond and clean the drains every 4-5 years. Excavations carried out manually by hiring people to dig sludge from the pond and placed on the outskirts of the pond. It requires a long time since one unit of the ave-rage farm area of $2-4$ ha. Other infrastructure is the quality of sluice gate is also not good, since most of them are made of wood, so it is often easily broken. Sluice serves as the control of 
water in and out. The government can build access roads and provide excavator and farmers may rent it with affordable price to rehabilitate their ponds

Farmers only use natural food and there is no other additional food from outside. Natural food, which is called klekap by local farmers, can grow naturally by giving some fertilizers in to ponds. Klekap are microorganisms composed of blue algae, benthos, diatoms, bacteria and microscopic organisms animal, which actually good for the growth and development of fish and tiger shrimp. Research conducted by Andayani (2012), showed the presence of a large correlation between the abundance of klekap on the growth of milkfish and tiger shrimp.

The sensitive attribute in technologyinfrastructure dimension is aquaculture technology. In this study, the site is still simple and traditional. The Government through Department of Marine and Fisheries, West Kalimantan Province and Sambas district has the program and guidance for the application of Good Aquaculture practice (GAP). Based on observations in the study area and interviews to fish farmers, they do not fully applied GAP because quite a lot of stages and procedures must be followed through by farmers, such as water supply, the layout and design of the pond, the cleanliness of the facility, equipment preparation of container cultivation, good water management, use of seed, feed, chemicals, transportation of handling, waste disposal, water quality records, a record number of harvest, the date and the location of the seller and the buyer. In the future, GAP application must be done to ensure food security and sustainability of the small-scale farms.

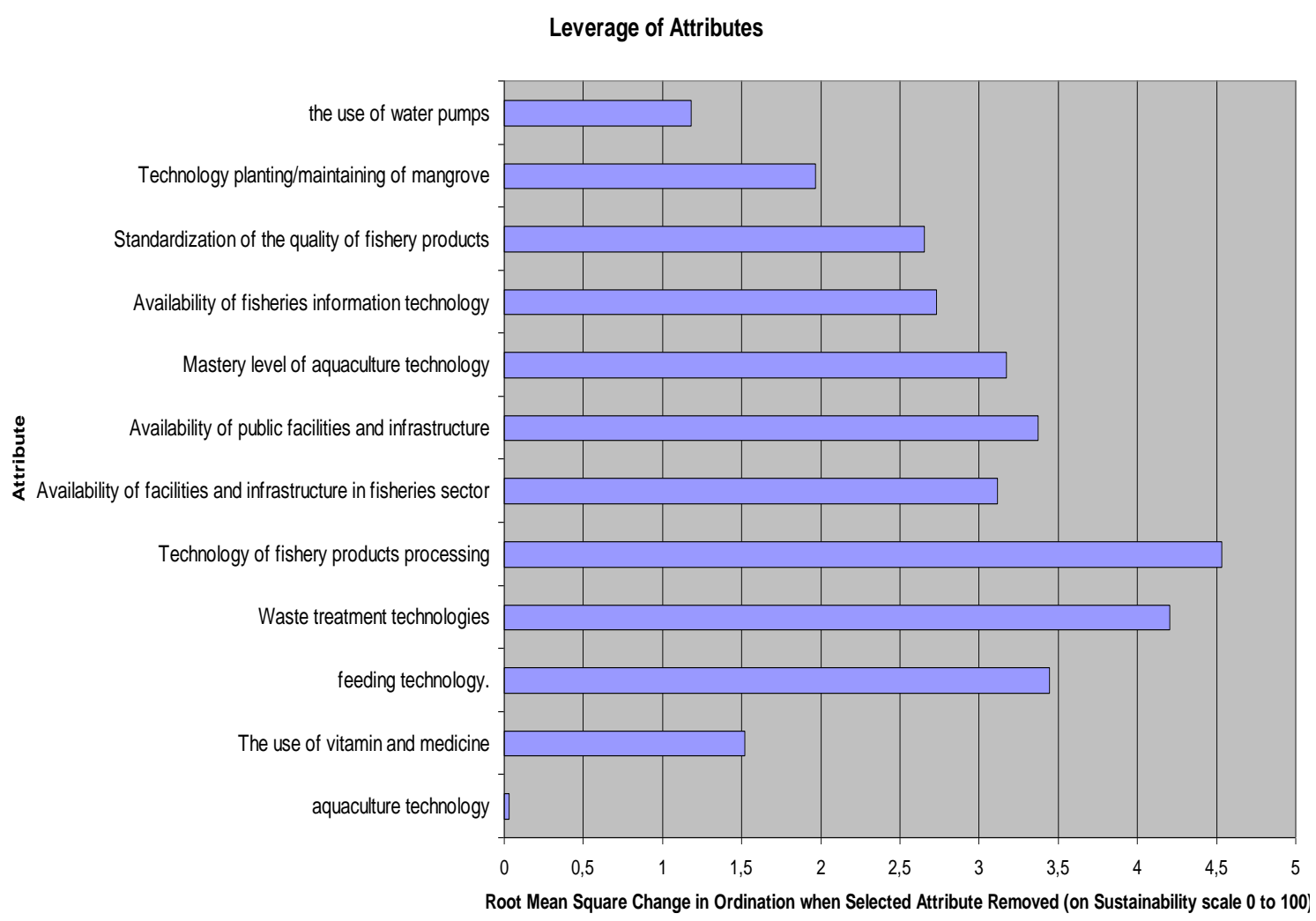

Figure 6a. Sensitive attributes affecting sustainability of technology-infrastructure dimensions in fishery pond polyculture with mangrove integration. 


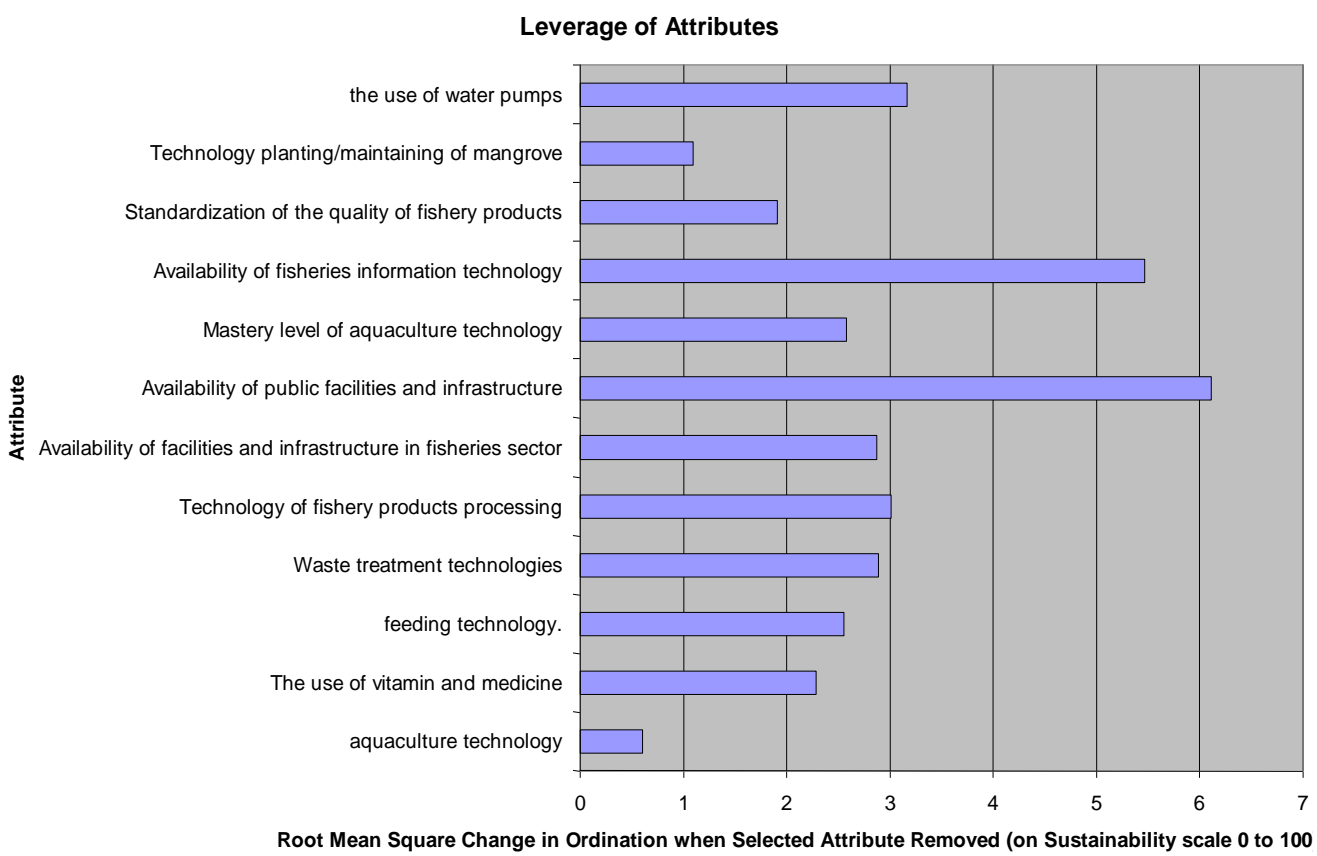

Figure $6 \mathrm{~b}$. Sensitive attributes affecting sustainability of technology-infrastructure dimensions in fishery pond polyculture without mangrove integration.

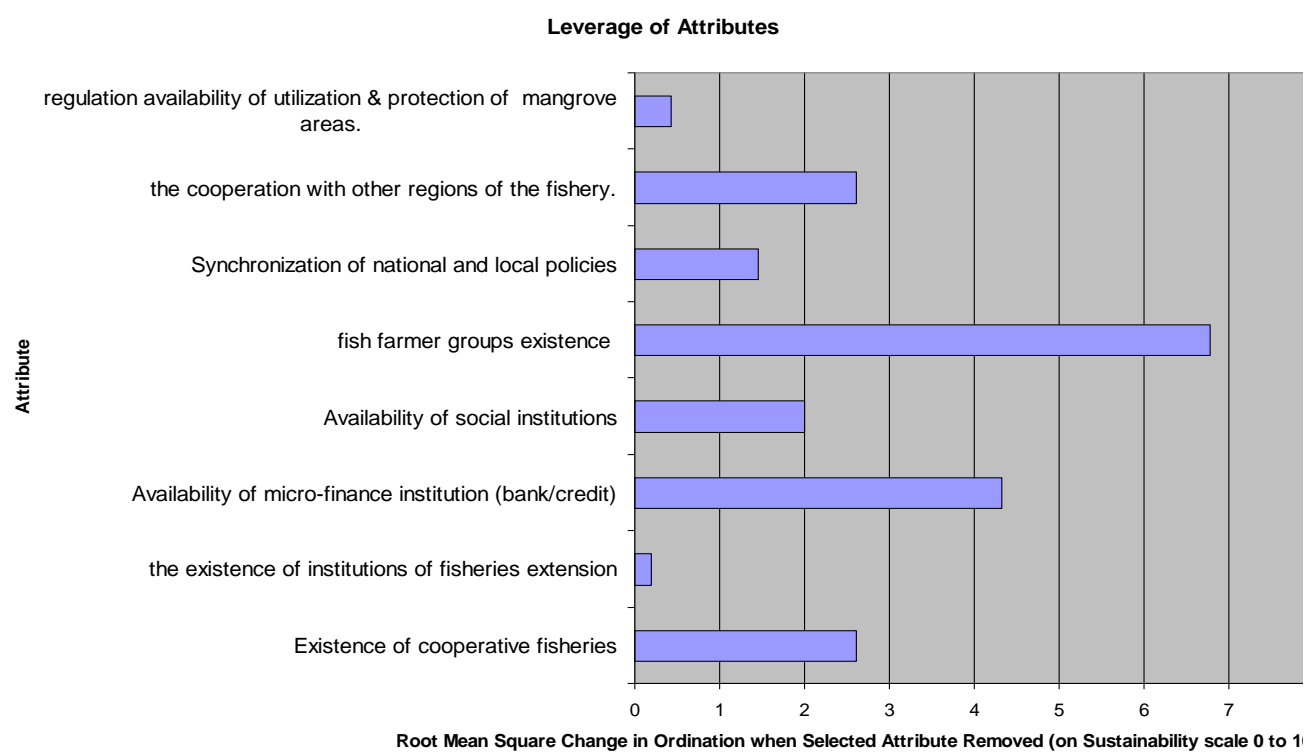

Figure 7a. Sensitive attributes affecting sustainability of law-institutional dimension in fishery pond polyculture with mangrove integration.

\subsection{Law-Institution Dimension}

There were eight attributes that affected the sustainability of the law institutional dimension. According to the result from MDS using Rapfish, sustainability index of both polyculture fishery ponds was less sustainable (39,91 and 35,82 respectively).
There were two sensitive attributes of law-institutional dimension on fishery pond polyculture with mangrove integration, i.e the fish farmer group existence and availability of micro finance institution (Figure. 7a), and six sensitive attributes (availability of micro finance institution, availability of social insti- 


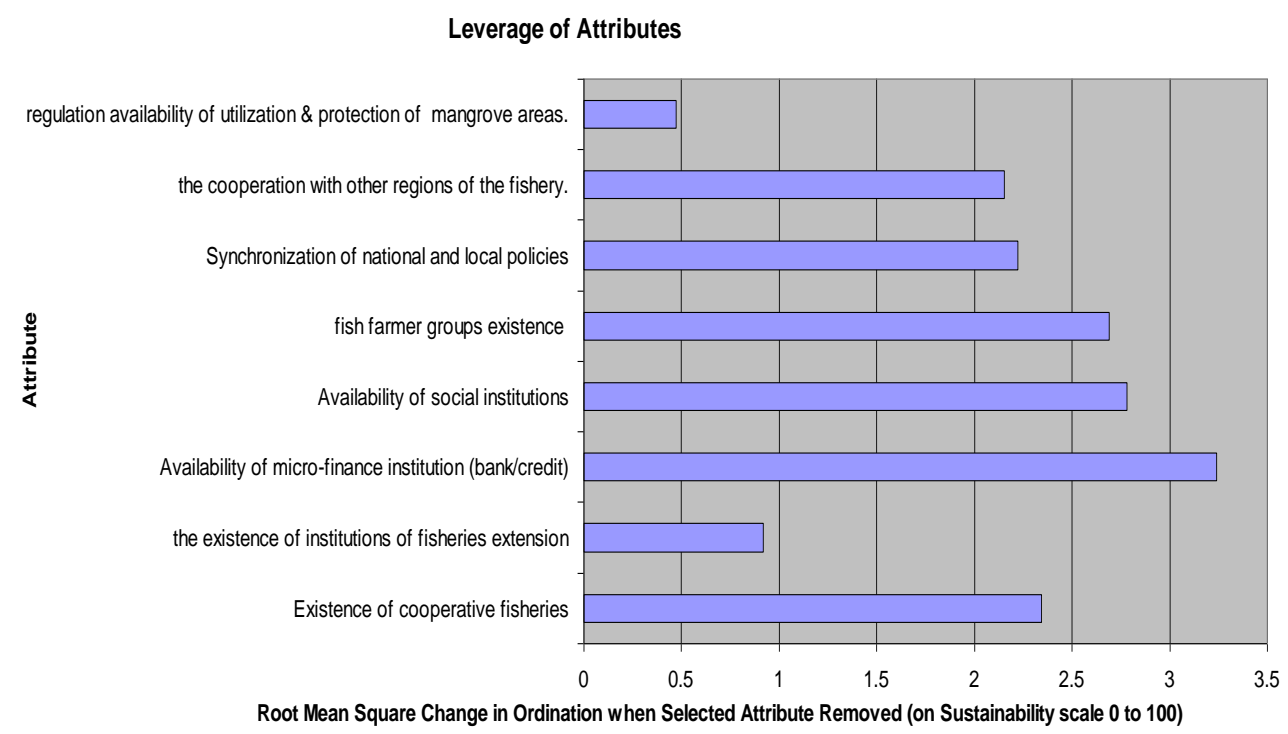

Figure $7 \mathrm{~b}$. Sensitive attributes affecting sustainability of law-institutional dimension in fishery pond polyculture without mangrove integration.

tution, fish farmer group existence, existence of cooperative fisheries, synchronization of national and local policies, the cooperation with other regions of the fishery) on fishery pond polyculture without mangrove integration (Figure $7 \mathrm{~b}$ ). Intervention to these attributes were have to be implemented in order to improve law-institutional sustainability.

Fish-farmers should create or join a group, in which farmers can share experiences about the management of their aquaculture or selling their products together with reasonable prices. The Governments can also facilitate the establishment of microfinance institutions, so that fish farmers have access to source of capital and funding. The essential role of the Central Government, the Government of West Kalimantan Province, and Sambas Regency as policy-makers is to do further research to create a business development programs in the future so that fish-farmers can conduct sustainable and self-sufficient farming.

Furthermore, we must realize that mangrove destruction would cause environmental damage, that in turn could lead to lower fishery production and threatened sustainability of the polyculture ponds in the region. Stakeholders, especially the local fishfarmers should develop the polyculture fish- pond with mangrove integration by planting mangroves inside and around fishery ponds.

\section{CONCLUSIONS}

Based on the existing conditions, the multidimensional sustainability status of polyculture fishpond with and without mangrove integration is less sustainable (sustainability index of 44,98 and 36,18 respectively). There are 16 and 23 sensitive attributes respectively that affect the sustainability of polyculture fishpond with and without mangrove integration. In order to improve the sustainability index, all sensitive attributes should be improved. As a priority in improving the sustainability index, stakeholders needs to make improvements on the most sensitive attributes in each dimension, because the greatest sensitivity values that are expected to raise the sustainability index of fishery ponds immediately. So, polyculture fishery pond for small-scale farms will be sustainable in the future.

\section{ACKNOWLEDGEMENTS}

We would like to express our sincere gratitude to the Ministry of Research and 
Higher Education of Republic of Indonesia for funding this research. We are grateful to Gadjahmada University and Tanjungpura University for all supports that enabled us to complete this research. We would also like to thank students and villagers who assisted us in data collection in the field. Special thanks to reviewers and the editorial board for their helpful comments, and suggestions for this manuscript.

\section{REFERENCES}

Akiyama, D. M. and A. M. Anggawati. 1999. Polyculture of shrimp and tilapia in East Java. American Sybean Association (ASA), Technical Bulletin AQ. 7$10 \mathrm{pp}$.

Alder, J., T. J. Pitcher, D. Preikshot, K. Kaschner, and B. Ferriss. 2000. How good is good? A rapid appraisal Stechnique for evaluation of the sustainability status of fisheries of the north Atlantic. In: Pauly, D. Pitcher, T.J. (eds.). Methods for evaluating the impacts of fisheries on North Atlantic ecosystems. 136-182pp.

Allahyari, M.S. 2010. Social sustainability assessment of fishery cooperatives in Guilan Province, Iran. J. of Fisheries and Aquatic Sciences, 5(3):216-222.

Andayani, S. 2012. Pengaruh kelimpahan klekap di tambak tradisional terhadap pertumbuhan ikan bandeng dan udang windu. Berk. Penel. Hayati, 17:159163.

Baeta, F., A. Pinheiro, M. Corte-Real, J. Lino Costa, P. Raposo de Almeida, H. Cabral, and M.J. Costa. 2005. Are the fisheries in the Tagus estuary sustainable?. Fisheries Research, 76:243251.

Bocek, A. 2015. Water harvesting and aquaculture for rural development, Introduction to polyculture of fish. International Center for aquaculture and Aquatic Environments, Auburn University, Alabama. Available from: http://www.ag.auburn.edu/fish/docum ents/International_Pubs/Water\%20Ha rvesting/English/Introduction $\% 20$ to $\%$ 20polyculture.pdf $>$. [Accessed 15 July 2016].

Bourgeois, R. and F. Jesus. 2004. Participatory Prospective Analysis, Exploring and Anticipating Challenges with Stakeholders. Center for Alleviation of Poverty through Secondery Crops Development in Asia and The Pacific and French Agricultural Reasearch Center for Internasional Development. Monograph, (46):1- 29.

Badan Pusat Statistik Sambas Sambas (BPS). 2013. Kabupaten Sambas dalam angka 2012. BPS, Sambas. 149p.

Bunting, S. W. 2006. Low impact aquaculture. Centre for Environment and Society Occasional Paper 3, Universty of Essex. UK. 10p.

Bunting, S. W. 2008. Horizontally integrated aquaculture development: exploring consensus on constraints and opportunities with a stakeholder Delphi. Aquaculture International, 16:153169.

Connel, D.W. dan Gregory J. M. 2006. Kimia dan ekotoksikologi pence-maran. Yanti Koestoer dan Sahati (penterjemah). Universitas Indonesia UI-Press. Jakarta. 520p.

Da Silva-Copertino M., T. Tormena, and U. Seeliger. 2009. Biofiltering efficiency, uptake and assimilation rates of Ulva clathrata (Roth) J. Agardh (Chlorophyceae) cultivated in shrimp aquaculture waste water, 21:31-45.

Darmono. 1991. Budidaya udang Penaeus. Kanisius. Yogyakarta. 104hlm.

Fahmi, 2000. Beberapa jenis ikan pemangsa di tambak tradisional dan cara penanganannya. Oseana., 25(1):21-30.

Food and Organisation Fisheries Department. 1997. Aquaculture development. FAO Technical Guidelines Responsi-ble Fisheries. 40p. 
Garcia, M., J. Staples, and J. Chesson. 2000. The FAO guidelines for the development and use of indicators for sustainable development of marine capture fisheries and an Australian example of their application. Ocean and Coas-tal Management, 43(7):537-556.

Hogarth, P.J. 1999. The Biology of Mangrove. Oxford University Press, inc. New York. 228p.

Islam, Md. Shahidul. 2005. Nitrogen and phosphorus budget in coastal and marine cage aquaculture and impacts of effluent loading on ecosystem: review and analysis towards model development. Marine Pollution Bulletin, 50:48-61.

Kathiresan, K. dan B.L. Bingham. 2001. Biology of Mangrove and Mangrove Ecosystems. Advances in Marine Biology. J. of Marine Sciences, 40: 81251.

Kavanagh, P. and T.J. Pitcher. 2004. Implementing microsoft excel software for rapfish: A technique for the rapid appraisal of fisheries status. Fisheries Centre Research Reports 12(2), The Fisheries Centre, University of British Columbia. Canada.75p.

Kioussis, D.R., F.W. Wheaton, and P. Kofinas. 2000. Reactive nitrogen and phosporus removal from aquaculture wastewater effluents using polymer hydrogels. Aquacultural Engineering, 23:315-332.

Markus, M. and Burhanuddin. 2014. Uji lapang teknologi polikultur udang windu (penaeus monodon fabr.), ikan bandeng (chanos chanos forskal) dan rumput laut (Gracilaria verrucosa) di tambak desa Borimasunggu Kabupaten Maros. J. Saintek Perikanan, 10 (1):30-36.

Martínez-Porchas M., L. R. MartínezCórdova, M.A. Porchas-Cornejo, J. López-Elías. 2010. A. Shrimp polyculture: a potentially profitable, sus- tainable, but uncommon aquacultural practice. Rev Aquacult., 2:73-85.

Muangkeow B., K. Ikejima, S. Powtongsook. 2007. Effects of white shrimp, Litopenaeus vannamei (Boone), and Nile tilapia, Oreochromis niloticus L., stocking density on growth, nutrient conversion rate and economic return in integrated closed recirculation system. Aquaculture, 269:363-376.

Nathanael, Hishamunda and Neil B. Ridler. 2002. Macro policies to promote sustainable commercial aquaculture. Kluwer Academic Publishers. Printed in the Netherlands. Aquaculture International, 10:491-505.

Badan Pusat Statistik Sambas (OECD). 1993. Coastal Zone Management: Integrated Policies. OECD, Paris. 126p.

Pitcher, T.J. 1999. Rapfish, A Rapid Appraisal Technique for Fisheries, and Its Application to the Code of Conduct for Responsible Fisheries. FAO Fisheries Circular. FAO, Rome. 947p.

Pitcher, T.J. and D. Preikshot. 2001. Rapfish: A rapid appraisal technique to evaluate the sustainability status of fisheries. Fisheries Research, 49:255 -270.

Pramudji. 2000. Hutan Mangrove di Indonesia: Peranan, Permasalahan dan Pengelolaannya. Oseana, 25(1):13-20.

Preikshot, D., E. Nsiku, T.J. Pitcher, and D. Pauly. 1998. An interdisciplinary evaluation of the status and health of African lake fisheries using a rapid appraisal technique. J. Fish Biol., 53(A):381-393.

Ronnback, P., M. Troell, N. Kautsky, and J.H. Primavera. 1999. Distribution pattern of shrimps and fish among Avicennia and Rhizophora microha-bitats in the Pagbilao mangroves, Philippines. Estuarine Coastal Shelf Science., 48:223-234.

Soeseno, S. 1988. Budidaya ikan dan udang dalam tambak. PT. Gramedia. Jakarta. 179hlm. 
Spalding, M., F. Blasco, and C. Field. 1997. World Mangrove Atlas. The International Society for Mangrove Ecosystems, Okinawa. Japan.178p.

Sudradjat, A. 2011. Panen bandeng 50 hari. Swadaya. Bogor. 84hlm.

Sugiyama, S., D. Staples, and S.J. FungeSmith. 2004. Status and potential of fisheries and aquaculture in Asia and the Pacific. FAO Regional Office for Asia and the Pacific. RAP Publication 2004/25. 53pp.

Surtida, M.B. 2000. Silvofisheries in Indonesia. SEAFDEC Asian Aquaculture, 22(6):21:28.

Tesfamichael, D. and T.J. Pitcher. 2006. Multidisciplinary evaluation of the sustainability of Red Sea fisheries using Rapfish. Fisheries and Aquatic Sciences., 5(3):216-222.

Thompson, M.H. 2008. Fostering sustainable behaviors in community- based comanaged fisheries. Marine Policy, 32:413-420.

Troell M., A. Joyce, T. Chopin, A. Neori, A.H. Buschmann, and J.G. Fang. 2009. Ecology engineering in aquacuture - potential for integrated multitrophic aquaculture (IMTA) in marine offshore systems. Aqua-culture., 297:1-9.

$\begin{array}{ll}\text { Diterima } & : 20 \text { September } 2016 \\ \text { Direview } & : 3 \text { November } 2016 \\ \text { Disetujui } & : 22 \text { Desember } 2016\end{array}$

